\section{Multifocal cutaneous Rosai-Dorfman disease masquerading as lupus vulgaris in a child ${ }^{*}$}

\author{
Aastha Gupta ${ }^{1}$ \\ Pooja Arora ${ }^{1}$ \\ Meenakshi Batrani ${ }^{2}$ \\ Prafulla Kumar Sharma ${ }^{1}$
}

DOI: http://dx.doi.org/10.1590/abd1806-4841.20187796

Dear Editor,

A 13-year-old girl presented to us with red plaques and nodules on her chest and ears for the past two years. The lesions gradually increased in size and were asymptomatic. The patient was otherwise healthy and had no significant past medical history. General physical examination was normal, with no lymph node enlargement. Cutaneous examination revealed multiple infiltrative erythematous plaques, nodules and scars on the right breast surrounding an area of central atrophy and hypopigmentation, which occurred due to the intralesional triamcinolone injections received by the patient from a local practitioner (Figure 1). There was a reddish-yellow nodule of $1 \mathrm{~cm}$ in size on the pinna of the left ear (Figure 2). There was no mucosal involvement.

Routine biochemical tests were normal. Histopathological examination revealed a dense pandermal infiltrate composed of histiocytes and admixed plasma cells, neutrophils, lymphocytes and multinucleate giant cells. Histiocytes had abundant eosinophilic to pale cytoplasm and occasionally an inflammatory cell was present within the cytoplasm suggestive of emperipolesis (Figure 3). Mild fibrosis was present intervening the infiltrate. Stain for acid fast bacilli (AFB) was negative. Immunohistochemical staining revealed that the histiocytes were positive for S-100, CD68 and CD163. CD1a staining was negative. Fungal and AFB cultures were negative. Based on the above findings a diagnosis of cutaneous Rosai-Dorfman disease (RDD) was made. Patient was advised excision of the lesions.

Received 29 October 2017.

Accepted 16 February 2018.

* Work conducted at the Department of Dermatology, Dr Ram Manohar Lohia Hospital, New Delhi, India.

Financial support: None.

Conflict of interest: None.

${ }^{1}$ Department of Dermatology, Dr Ram Manohar Lohia Hospital, New Delhi, India.

${ }^{2}$ Dermpath Laboratory, New Delhi, India.

MaIling AdDREsS

Pooja Arora

E-mail: drpoojamrig@gmail.com

○2018 by Anais Brasileiros de Dermatologia

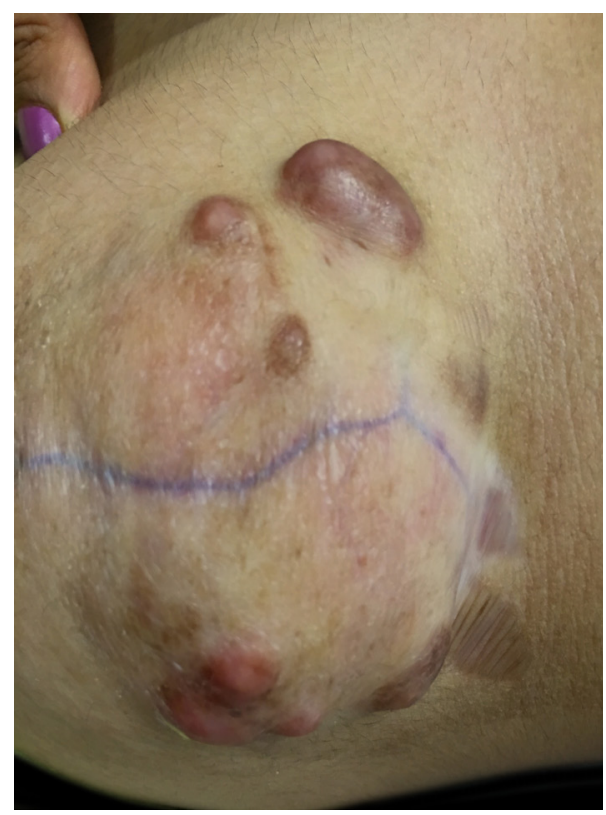

Figure 1: Multiple erythematous infiltrated plaques and nodules present on the right breast surrounding an area with atrophy, hypopigmentation and erythema

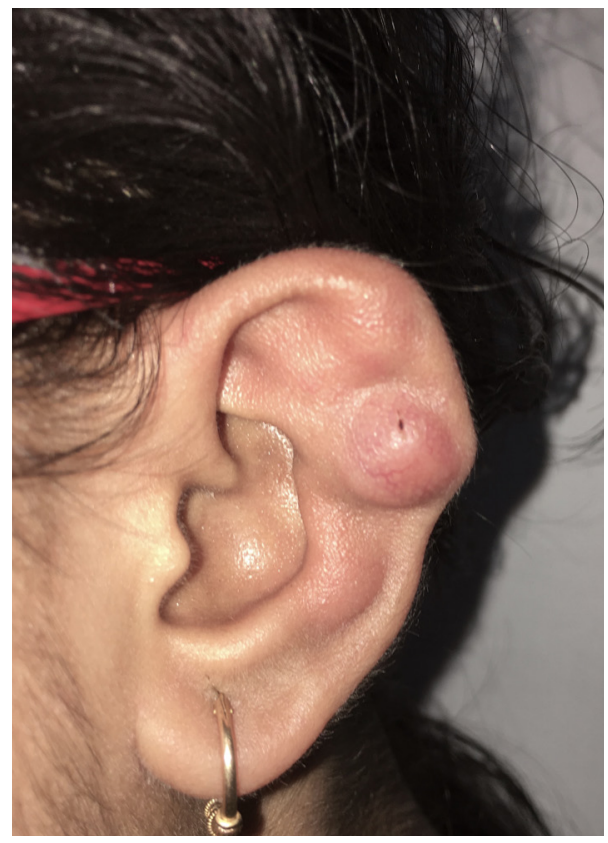

FIGURE 2: Reddish-yellow nodule with telangiectasia present on the pinna of the left ear

RDD, originally known as sinus histiocytosis with massive lymphadenopathy, is a benign histiocytic proliferative disorder characterized clinically by a massive, painless, often bilateral cervical lymphadenopathy accompanied by fever, neutrophilia, anemia, raised erythrocyte sedimentation rate and polyclonal hypergammaglobulinemia. ${ }^{1}$ Extranodal involvement is seen in $43 \%$ of cases with skin being the most commonly affected site. The term cutaneous Rosai-Dorfman disease (CRDD) is used to describe the rare form of RDD which involves the skin exclusively with no involvement of lymph nodes or other sites. 
The etiology of RDD remains unknown. It is believed that RDD represents an exaggerated immune response to an infectious agent due to the polyclonal nature of infiltrating cells and the clinical course of the disease. Epstein-Barr virus, human herpesvirus 6,

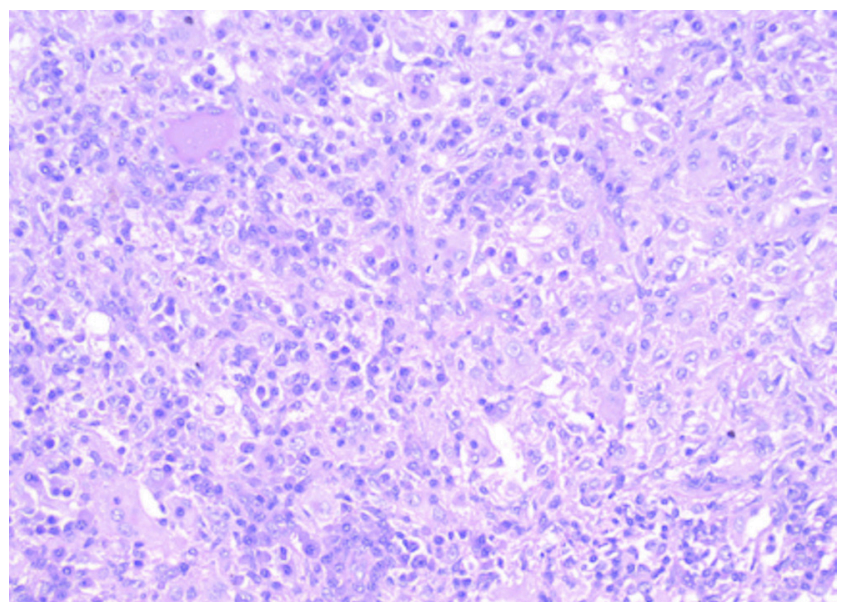

Figure 3: Dermal infiltrate composed of histiocytes, giant cells and numerous plasma cells. Emperipolesis of lymphocytes and plasma cells within histiocytes (Hematoxylin \& eosin, x400)
Brucella and Klebsiella have been found to be associated with RDD, but no definitive link has been established as yet.

The histologic features in cutaneous RDD include a dermal infiltrate of large polygonal histiocytes with abundant pale to eosinophilic cytoplasm admixed with an infiltrate of lymphocytes and plasma cells. Emperipolesis, which is the presence of intact inflammatory cells like lymphocytes within the cytoplasm of histiocytes, is highly suggestive of the disease. The CRDD histiocytes stain positively for S100, CD 163 and CD68, but are generally negative for CD1a. This microscopic and immunohistochemical constellation confirms the diagnosis of CRDD. However, increased amounts of fibrosis, less prominent emperipolesis and fewer histiocytes in cutaneous lesions may make the diagnosis difficult.

Contrary to systemic RDD, which primarily involves children and young adults and has a male predominance (1.4:1), cutaneous RDD tends to occur at an older age (median age, 43.5 years) with a reversed male to female ratio (1:2) and has been rarely reported in children. Majority of RDD patients are of African American descent while CRDD most commonly affects Caucasian and Asian individuals. Clinically, it has a variable presentation with isolated or disseminated slow-growing asymptomatic brown or yellow-red papules, nodules, plaques or tumors. The most common sites involved are the trunk followed by the head and neck region, lower and upper extremities. Our patient was a child who presented

\begin{tabular}{|c|c|c|c|c|c|c|c|c|c|}
\hline & Author & $\begin{array}{l}\text { Age, } \\
\text { gender }\end{array}$ & $\begin{array}{l}\text { Ethnicity/ } \\
\text { country }\end{array}$ & Site & $\begin{array}{l}\text { Type of } \\
\text { lesion }\end{array}$ & Duration & $\begin{array}{l}\text { Laboratory } \\
\text { findings }\end{array}$ & Treatment & Follow up \\
\hline 1 & Al-Khateeb ${ }^{1}$ & $4, \mathrm{M}$ & $\begin{array}{l}\text { Saudi } \\
\text { Arabia }\end{array}$ & $\begin{array}{l}\text { Right paro- } \\
\text { tid area }\end{array}$ & Nodule & 3 months & $\begin{array}{l}\text { Within normal } \\
\text { limits }\end{array}$ & $\begin{array}{l}\text { Surgical } \\
\text { excision }\end{array}$ & $\begin{array}{l}\text { No recur- } \\
\text { rence }\end{array}$ \\
\hline 2 & Kala et $a l^{2}$ & $10, \mathrm{M}$ & India & $\begin{array}{l}\text { Both eye- } \\
\text { lids }\end{array}$ & $\begin{array}{l}\text { Diffuse } \\
\text { swelling }\end{array}$ & $\begin{array}{l}\text { Few mon- } \\
\text { ths }\end{array}$ & $\begin{array}{l}\text { Within normal } \\
\text { limits }\end{array}$ & - & - \\
\hline 3 & $\begin{array}{l}\text { Mebazaa } \\
\text { et } a l^{3}\end{array}$ & $12, \mathrm{~F}$ & Tunisia & $\begin{array}{l}\text { Cheeks, } \\
\text { perioral } \\
\text { region, } \\
\text { upper } \\
\text { trunk, lo- } \\
\text { wer limbs }\end{array}$ & $\begin{array}{l}\text { Papules } \\
\text { and } \\
\text { nodules }\end{array}$ & 3 months & $\begin{array}{l}\text { Complete blood } \\
\text { count was } \\
\text { normal, elevated } \\
\text { ESR, polyclonal } \\
\text { hypergammaglo- } \\
\text { bulinemia }\end{array}$ & $\begin{array}{l}\text { Acitretin } \\
(20 \text { mg } \\
\text { daily for } \\
4 \text { months) } \\
\text { and surgi- } \\
\text { cal excision } \\
\text { of the large } \\
\text { lesions }\end{array}$ & $\begin{array}{l}\text { Improve- } \\
\text { ment in } \\
\text { lesions }\end{array}$ \\
\hline 4 & Jat et $a l^{4}$ & $6, \mathrm{~F}$ & India & Eyelids & $\begin{array}{l}\text { Diffuse } \\
\text { swelling }\end{array}$ & 3 years & $\begin{array}{l}\text { Anemia, } \\
\text { increased ESR, } \\
\text { hypergammaglo- } \\
\text { bulinemia }\end{array}$ & $\begin{array}{l}\text { Surgical } \\
\text { excision }\end{array}$ & $\begin{array}{l}\text { No recur- } \\
\text { rence }\end{array}$ \\
\hline 5 & Castillo $e t a l^{5}$ & $3, \mathrm{M}$ & Spain & $\begin{array}{l}\text { Upper lip, } \\
\text { trunk, and } \\
\text { limbs }\end{array}$ & Papules & 2 months & $\begin{array}{l}\text { Hypochromic } \\
\text { microcytic } \\
\text { anemia, high } \\
\text { immunoglobulin } \\
\text { A titers, slightly } \\
\text { high ESR }\end{array}$ & $\begin{array}{l}\text { Wait-an- } \\
\text { d-watch } \\
\text { approach }\end{array}$ & $\begin{array}{l}\text { Resolu- } \\
\text { tion of all } \\
\text { lesions } \\
\text { within } 6 \\
\text { months }\end{array}$ \\
\hline 6 & Gupta et al & $13, \mathrm{~F}$ & India & Chest, ear & $\begin{array}{l}\text { Nodules, } \\
\text { plaques }\end{array}$ & 2 years & Elevated ESR & $\begin{array}{l}\text { Plan for } \\
\text { surgical } \\
\text { excision }\end{array}$ & $\begin{array}{l}\text { No change } \\
\text { in lesions } \\
\text { since } 6 \\
\text { months }\end{array}$ \\
\hline
\end{tabular}


with multifocal disease involving the right breast and pinna of left ear. As per our knowledge there are only 5 cases of pediatric CRDD without lymph node involvement reported previously and none of them have shown involvement of the pinna as seen in our patient (Table 1). $\cdot^{1-5}$

CRDD can mimic histiocytoses, juvenile xanthogranuloma, sarcoidosis, lymphoproliferative disorders, tuberculosis, leishmaniasis and other infiltrative and infectious etiologies. In our patient there was a strong suspicion of lupus vulgaris. However, involvement of the ear aroused suspicion of infiltrative disorders like CRDD at the first visit. Other diseases involving the ear such as pseudolymphoma, leprosy, perichondritis and relapsing polychondritis were clinically ruled out in our case.

Most patients with CRDD have a self-limiting and benign clinical course and spontaneous resolution is frequent. Treatment is required only in symptomatic cases or those with disseminated disease. Corticosteroids, thalidomide, alkylating agents, retinoids, radiotherapy, and surgical excision have been used previously. Although progression to systemic disease has not been reported, nevertheless, follow-up of CRDD patients is recommended to exclude any possible recurrence or subsequent development of systemic disease. $\square$

\section{REFERENCES}

1. Al-Khateeb TH. Cutaneous Rosai-Dorfman Disease of the Face: A Comprehensive Literature Review and Case Report. J Oral Maxillofac Surg. 2016;74:528-40.

2. Kala C, Agarwal A, Kala S. Extranodal manifestation of Rosai-Dorfman disease with bilateral ocular involvement. J Cytol. 2011;28:131-3

3. Mebazaa A, Trabelsi S, Denguezli M, Sriha B, Belajouza C, Nouira R. Extensive purely cutaneous Rosai-Dorfman disease responsive to acitretin. Int J Dermatol. 2007:46:1208-10.

4. Jat KR, Panigrahi I, Srinivasan R, Singh U, Vasishta RK, Sharma N, et al. Cutaneous Rosai Dorfman disease: presenting as massive bilateral eyelid swelling. Pediatr Dermatol. 2009;26:633-5.

5. Toledo del Castillo B, Mata-Fernández C, Rodríguez Soria VJ, Parra Blanco V Loughlin G, Campos-Domínguez M. Self-Healing Extranodal Cutaneous RosaiDorfman in a Child. Pediatr Dermatol. 2015;32:249-50.
Multipuncture technique with ingenol mebutate in the treatment of a periungual wart ${ }^{*}$

Gerson Dellatorre

Anarosa Barbosa Sprenger ${ }^{1}$

DOI: http:/ / dx.doi.org/10.1590/abd1806-4841.20187820

Dear Editor,

Periungual warts (PW) are very common and frequently encountered in the clinical setting. A variety of treatment modalities have been reported, including topical, intralesional, systemic, and surgical approaches. ${ }^{1}$ Despite the existence of several treatment approaches, PW are still characterized by their therapeutic resistance.

We report a case of a 37-year-old female patient presenting a recalcitrant PW on her left thumb (Figure 1). Previous treatments included cryotherapy (15 treatments) and imiquimod 5\% cream (3 times a week for 8 weeks), without improvement.

We applied ingenol mebutate (IM) gel (Picato ${ }^{\circledR}, 0.05 \%$, LeoPharma, Balerup, Denmark) using a multipuncture technique. After skin antisepsis with clorexidine $0.2 \%$ solution, IM $0.05 \%$ gel was applied over the lesional area $(4 \times 4 \mathrm{~mm})$ and 150 superficial punctures per treatment were made with a $31 \mathrm{G}$ needle. The treatments were repeated 3 times at 15-day intervals. Fifteen days after the third procedure, complete resolution was observed (Figure 2). Regarding to adverse effects, only mild desquamation occurred after each application.

IM gel has been effective against human papilloma virus (HPV) lesions, as shown previously in two case series of genital warts, with total lesional clearance in 18 of 19 patients. ${ }^{2,3}$ The therapeutic response observed in our case suggests that IM can also be a therapeutic modality in more keratotic HPV-related lesions, such as PW, since drug penetration can be improved by multipuncture technique. $\square$

Received 05 November 2017.

Accepted 20 January 2018.

* Work conducted at the Hospital Santa Casa de Curitiba, Curitiba (PR), Brazil.

Financial support: None.

Conflict of interest: None.

1 Department of Dermatology, Hospital Santa Casa de Curitiba, Curitiba (PR), Brazil.

MaILING AdDRESS:

Gerson Dellatorre

E-mail: dellatorre@gmail.com

C2018 by Anais Brasileiros de Dermatologia (c)) BY-NC

Multifocal cutaneous Rosai-Dorfman disease masquerading as lupus vulgaris in a child. An Bras Dermatol. 2018;93(5):766-8. 